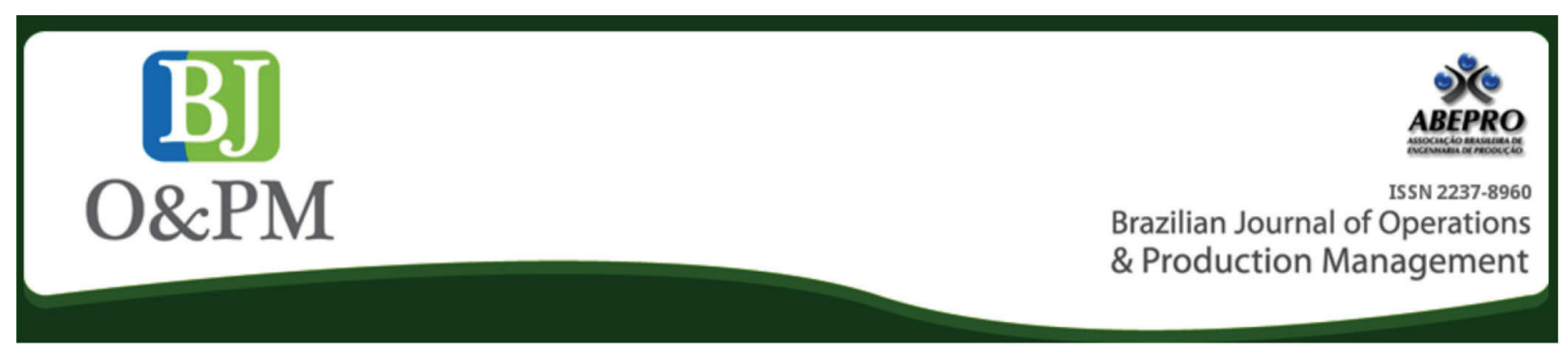

\title{
SUSTAINABLE PLANNING OF A NEW CITY IN MOZAMBIQUE
}

Pedro Bettencourt Coutinho nemus@nemus.pt NEMUS - Environmental Management and Requalification, Portugal

\begin{abstract}
Careful Land and urban planning is of extreme importance in developing countries with fast growing population as Mozambique. Environmental Strategic Assessment (SEA) and Environmental and Social Impact Assessment (ESIA) are management instruments to early predict urban development potential impacts and risks, contributing to support the shaping of sustainable planning, and avoiding the social and environmental havoc of inadequate development. The objective of this paper is to present the contribution of SEA and ESIA in the planning process of a new major city in southern Mozambique, in Katembe district, facing Mozambique's capital Maputo. The Katembe City's environmental and social assessment process highlighted the environmental, socioeconomics and cultural particularities of this territory and identified the critical constraints for urban development. A preliminary assessment avoided major negative potential impacts, but required specific environmental and social detailed studies to be addressed in the new city's partial urban plans. When these studies were completed, the new urban detailed plans included all the necessary environmental requirements to avoid/mitigate flooding, coastal erosion, and biodiversity loss and habitat fragmentation. It is expected that this experience will encourage the wider application of sustainable urban planning in shaping new urban areas in Mozambique and other fast developing countries.
\end{abstract}

Keywords: Mozambique; Sustainable Urban Planning; Liveability. 


\section{INTRODUCTION}

According to Godschalk (2004), for efficient urban planning the focus should be given, not only to the conciliation of economics, environment and (social and intergenerational) equity, but also to the careful account of the territory.

This integration is proposed within the sustainability / liveability prism, a framework for understanding and expressing the constraints to development (cf. Figure 1). The dimension of liveability comprises the three-dimensional aspects of public space, such as mobility and architectural production, to which one can add spontaneous appropriation of public space, especially relevant in Mozambique and in Katembe. To achieve liveability the following key dimensions must be integrated and balanced (cf. Grieve et Weinspach, 2010):

- Social and cultural capital, historical and ethnographic heritage;

- Aspects of nature and environmental systems' conservation and requalification required for human well-being;

- Considerations of adequate and sufficient income to assure basic living conditions.

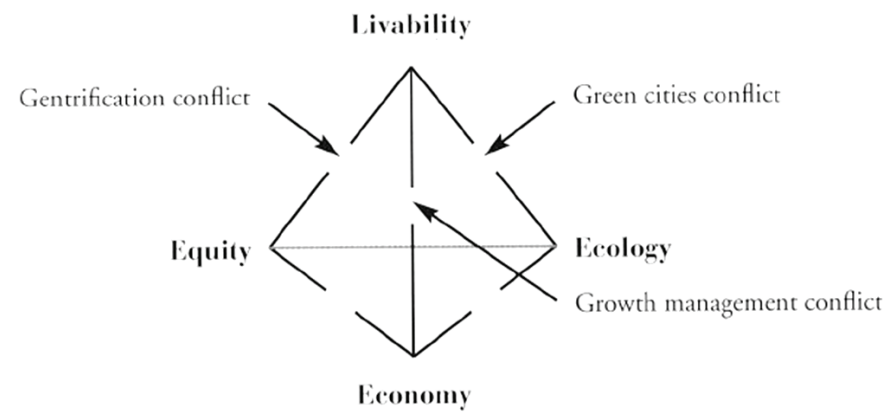

Figure 1. Sustainability / liveability prism Source: Godschalk (2004)

A new urban development of a territory usually introduces unbalances and tensions between these dimensions (conflicts in Figure 1), the result of pre-existent cultural aspects that are changed with a specific urban project. Hence, the instance of urban planning should be used to anticipate and prepare for a new equilibrium between these key dimensions, including one with population's improved quality of life. In this process, a form of planning that is flexible, adaptive, and which involves the population's participation is particularly relevant.

As stressed by Godschalk (2004), scale is important in assessing and dealing with conflicts arising between sus- tainability dimensions and liveability, and it is proposed as an effective way to deal with scale and design of plans at each relevant scale, which should be integrated, but able to work alone. In this context, the relationships among plans, places and people can be usefully understood as an ecology of plans (following the ecological alternative approaches of Steiner, 2002, and Beatley et Manning, 1997), which contribute to the creation of sustainable of liveable places.

When it is foreseen that a specific urban development can be linked to a major project (e.g. a major highway), attention to the regional scale can also be very valuable. In fact, the social and environmental effects derived from large projects are frequently not completely evident, but can act cumulatively through space and time. This issue is explored in cumulative impact assessments (cf. Teixeira, 2013; IFC, 2013; Hegmann et al., 1999).

The study area in Southern Mozambique is limited in the North by the Espírito Santo Estuary and Maputo Bay, in the East by the Indian Ocean, in the South by the South African Republic and the West by River Tembe and the dividing line between the administrative posts of Bela Vista and Catuane (Figure 2). It comprises the Municipal District of Katembe, and the District of Matutuíne, in Maputo Province.

Katembe is a traditionally rural territory at the banks of Maputo Bay. While distant from Maputo City only $2 \mathrm{~km}$ across the Espírito Santo estuary, the district of Katembe is currently 1 hour apart by ferry boat, and more than $100 \mathrm{~km}$ apart through a not fully paved road, which can be blocked in poor weather events.

The District of Matutuíne comprises Maputo Special Reserve (a pristine natural park in a coastal dune environment) and the scenic coastline extending from Machangulo in the North to Ponta do Ouro in the South. The Republic of South Africa's border is nearly $90 \mathrm{~km}$ south of Katembe.

This region, particularly the district of Katembe, is subjected to increasing pressure for urban development, due to the growing population of Maputo City, Mozambique's Capital City. Considering the predictions of the National Institute for Statistics of Mozambique and the World Bank, it is expected that the population in Maputo metropolitan area will double the present 2 million inhabitants in 20 to 30 years.

Expanding Maputo to the north is not an adequate option as the urban areas there are already very constrained, and the havoc of unplanned urbanization is a reality. Given the lack of areas for the expansion of Maputo City, a major social problem related to the lack of housing is envisaged in the region in the next decades. 
Thus, it is expected that, at least, part of the required expansion of Maputo will be made to Katembe territory. A program to improve accessibility from Katembe to Maputo City is already under construction. The same project will position the Republic of South Africa's border within one-hour distance from Katembe and Maputo City's centre.

Katembe rural territory is already the stage of intense spontaneous land occupation with informal settlements and the transaction of land use rights (República de Moçambique, 1997). Hence and regardless of the improved accessibilities, Katembe's native population is expected to increase from 19 thousand in 2007 to more than $\mathbf{4 0}$ thousand in the next decade.

Unplanned urban areas constitute a social problem because of the lack of pre-existent infrastructures required for adequate living conditions (roads, sanitation, and utilities), aggravated by the unruled spatial distribution of housing, including low lying areas prone to flooding.

The worst-case scenario was foreseen and motivated the Mozambican's Government decision to build a proper new urban centre in Katembe, aimed to accommodate 400.000 inhabitants in the next 20-25 years. For this purpose, a complex planning process was initiated in 2011 and is still going on. To date, three major planning phases were accomplished, and the authors of this paper were the leading consultants (on behalf of Mozambique's Ministry of Public Works) for the strategic and environmental assessments (SEA and ESIA; cf. República Portuguesa, 2007; 2011; República de Moçambique, 2015).

In this context, the present paper presents how Katembe's environmental and social issues were used to shape the sustainable urban planning of the new city.

A state-owned company, Maputo Sul E.P., was created in July 2011, to prepare the planning process that was initiated in October of the same year. The urban plans and the environmental and social studies took place between 2011 and 2016. Following, the city's construction began in 2015, and its main accesses are currently in completion: the bridge to Maputo City and the highway connecting the Republic of South Africa.

The planning for the new city followed ambitious objectives of environmental sustainability and social inclusion, in the aftermath of the disastrous effects of the floods of February 2000, which swamped all this territory, took hundreds of human lives and originated thousands of displaced (Direcção Nacional de Gestão Ambiental, 2006).

In the following sections are presented the Methodology of Katembe's planning (section 2), the environmental and socioeconomic Background (section 3), the environmental and social impacts assessment (section 4), the discussion (section 5), and a summary and conclusions (section 6).

\section{METHODOLOGY}

Having into account sustainability and liveability concerns, Katembe's new city planning followed a sequential approach, beginning with large scale planning (at a regional level), following with medium-size planning (general or master plans) and reaching local scale plans (urban detailed plans), incorporating, thus, four phases of planning, comprising different products:

1. Regional Land Management Plan Katembe - Ponta do Ouro, for Katembe and Matutuíne Districts (Betar et al., 2012a);

2. Master Plan for the Urbanization of Katembe City (Betar et Promontório Architects, 2012);

3. Architecture and Urban Planning Partial Plans for Katembe City sections (Betar et Promontório Architects, 2013a; 2013b);

4. Engineering Projects for roads and accessibilities, bridges, water and sanitation, electricity, and other.

Parallel to the planning process, and in an interactive way, environmental and social studies were developed, intended to, and resulting in, the integration of the sustainability and environmental issues in the planning process:

1. Strategic Environmental Assessment of the Regional Katembe-Matutuine Land Management Plan (Betar et al., 2012b);

2. Background studies concerning river flow and flood risk assessment, climate change and coastal and estuarine hydrodynamics and biodiversity and nature conservation (Betar et al., 2012c);

3. Environmental and Social Impact Assessment of Katembe City Master Plan (Betar et BETA, 2012);

4. Environmental and Social Impact Assessment of Urban Detail Plans for Katembe City sections 3 and 10 (Betar et BETA, 2013a; 2013b);

In this process, which engaged teams of architecture, engineering, urban planning, and environment and social sciences, the development of specific studies concerning environmental and social vulnerabilities and risks was crucial for the planning process. 


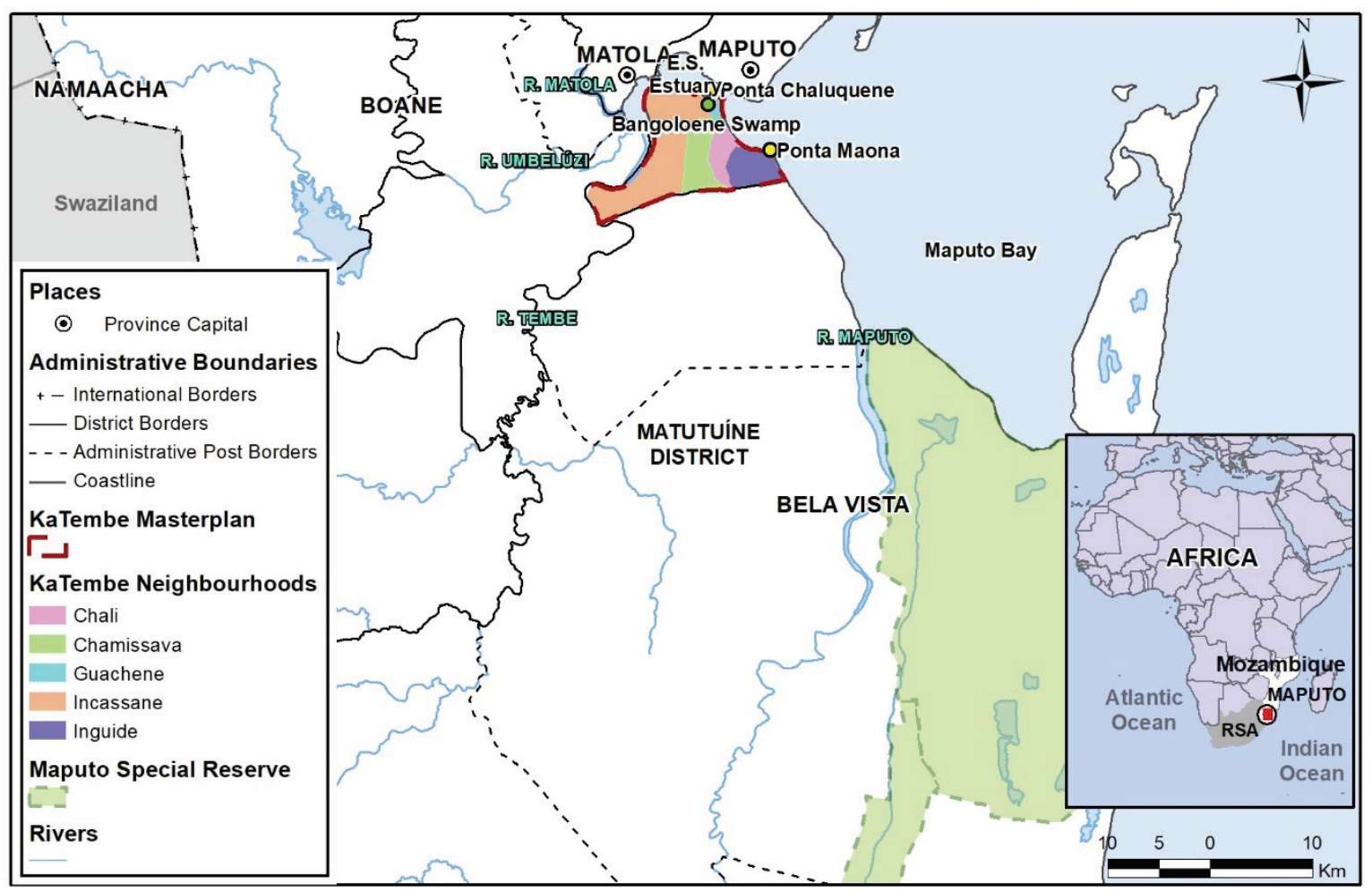

Figure 2. Katembe's geographic background Source: The author(s)' own

The planning and environmental and social assessment process comprised several instances for public and institutional participation, including public sessions enabling the participation of any citizen.

\section{The entire process is detailed in the following}

The first phase started with the Regional Land Management Plan for Katembe and Matutuíne Districts. In parallel, the sustainability and social concerns of the region were addressed in this phase through a Strategic Environmental Assessment (SEA) exercise.

The SEA conducted the selection of the best location for the new city, as the principal urban center in the region, while also assessing its main accessibilities: a suspended bridge across Maputo Bay for the West, and a highway connecting the South African border for East and South. Furthermore, the Regional Plan proposed a framework of secondary (smaller) urban developments, as well as a set of conservation areas, including a trans-boundary park ( $\mathrm{Li}$ bombos), connecting neighboring Swaziland and Republic of South Africa natural parks (Figure 3).

The second planning phase comprised the Master Plan for the Urbanization of Municipal District Katembe, where the main structure of the city was designed, including the lo- cation and composition of residential, commercial, touristic, leisure, recreational, industrial, and mixed areas. This design was directly influenced by the ESIA process performed in parallel with the Master Plan. Both processes included public consultations, as well as a varied array of focus group discussions with NGOs, government officials and Maputo City Council planners and managers.

An important issue in this design phase was a set of specialized studies to address critical aspects of this territory. The first comprised a study of coastal dynamics, coastal evolution and climate change potential risks, while the second included the assessment of river discharges and flooding risks (no less than six big rivers cross this region into Maputo Bay). A third study was dedicated to biodiversity and nature conservation.

With the conclusion of the second planning phase, regional and national authorities approved and published, on Mozambican Government Official Journal, the new city's Master Plan (Plano Parcial de Estrutura Urbana da Katembe). After a final set of public discussions, the Ministry of Environment issued a global environmental permit, including in the city's environmental license, several restrictions and recommendations for environmental and social compliance.

The license required additional environmental studies to be conducted in the next planning phase, particularly to be ad- 


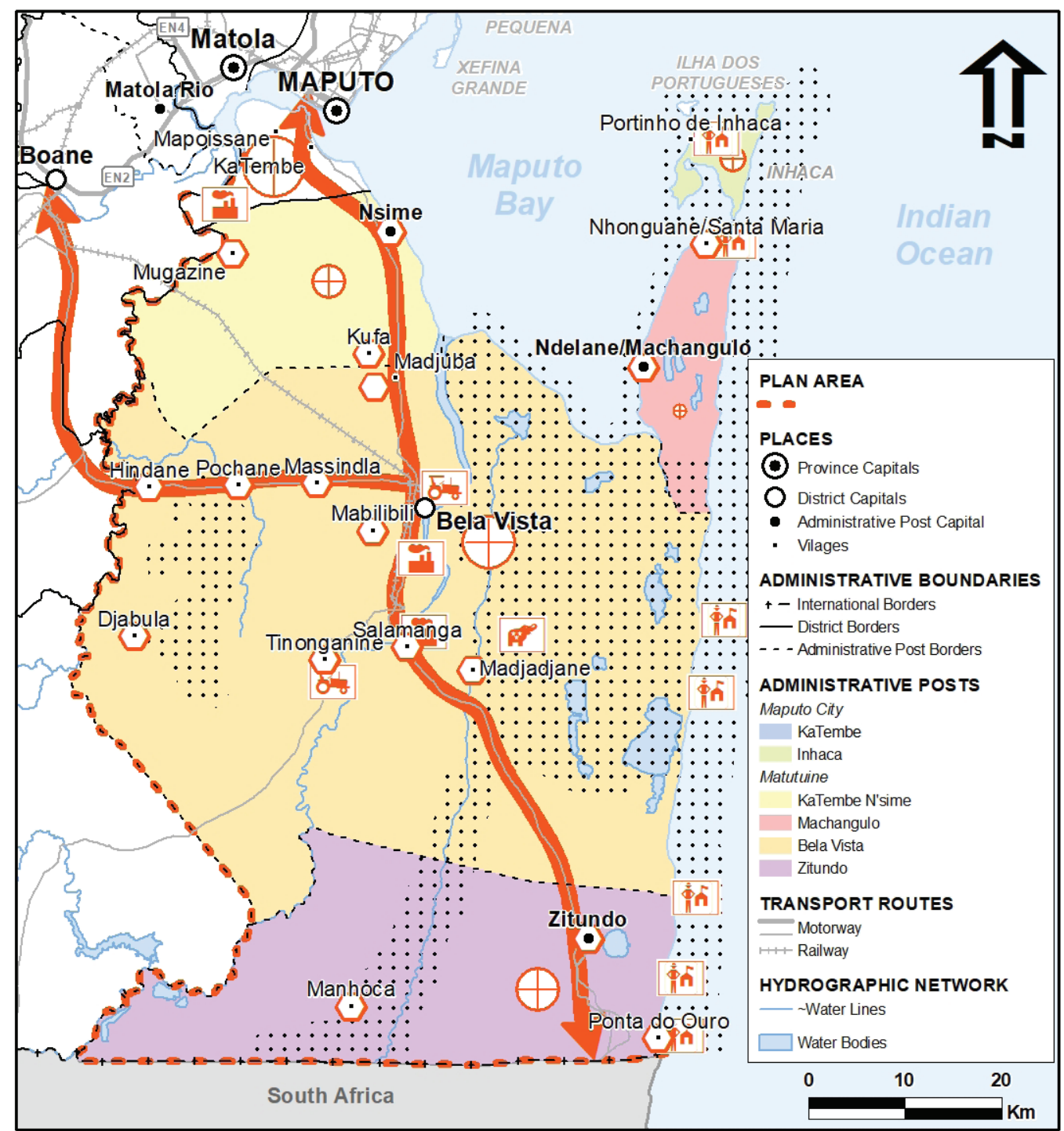

- PLAN AREA

. ENVIRONMENTAL PROTECTION AND VALUATION STRUCTURE

$\checkmark$ RURAL CENTRE OF COLECTIVE EQUIPMENT AND PROXIMITY SERVICES

U uRBan dEVELOPMENT CENTRE

\section{NEW MOTORWAY ACCESS}

핳항 AGRICULTURAL DEVELOPMENT CENTRE

* nature turism deVelopment Centre

"în "SUN AND SAND" TOURISM RESORTS DEVELOPMENT CENTRE

II. INDUSTRIAL DEVELOPMENT CENTRE

Figure 3. Land use model from Regional Land Management Plan Katembe - Ponta do Ouro Source: Adapted from Betar et al. (2012a) 
dressed in the detail plans of each of the city's sectors (the Master Plan divided Katembe city in 13 major areas, each to be detailed by an urban detailed plan). The Ministry of Environment decision also raised the need for a resettlement action plan, either for each of the city's urban areas, and for the construction of the city's territorial links (bridges, highways, harbors, etc.).

The third planning phase comprised the detailed design of the city's main urban sectors, as well as the detailed design of the principal infrastructure. This included the design of streets, roads, and parking spaces, water, energy, and telecommunications networks, parks and recreational areas, and sewage and water treatment plants.

This detailed design phase was also accompanied by environmental and social assessment processes, including one independent ESIA process for each urban sector. To date only two of these ESIA processes were concluded (priority areas 3 and 10). The ESIA contributed to a more sound and sustainable urban design, having approached each territorial specifications and vulnerabilities, either physical, ecological, and social.

However, the critical issue in this third phase was the Resettlement planning. To build these urban sections the ESIA estimated that, approximately, 350 families in area 3, and 280 in area 10 should be displaced, either to adjacent rural areas (for those who decided to continue their farming activities) or to the new urban areas (for those opting to remain in the city). Two Resettlement Action Plans were thus initiated in this phase (one for each area); however, due to lack of government and municipal funds, these processes yet remain to be finished.

The territorial plans and environmental and social studies were revised and finally approved by competent authorities: the Maputo Municipality Council and the Environment Ministry. The respective approval decisions were published in official journals.

After this phase for planning and territory management consensus building, the consolidation of the sustainability objectives requires the continuation of the process. The completion of the participatory processes regarding resettlement and social compensation of the affected population is particularly necessary.

\section{BACKGROUND}

\subsection{Physical environment}

Katembe's area is characterized by gentle to nearly flat landforms, forming a coastal plain composed of a wide sand dune system. The altimetry is under $50 \mathrm{~m}$, lowest at the riverside and alluvial plain of Bangoloene swamp (bellow 10m, $33 \%$ of the total city area). Some steep slopes are found in this coastal plain associated to different erosion resistance of the geological units or with present sand extraction activities (Betar et BETA, 2012).

The hydrographic network is poorly developed in Katembe. The Espírito Santo Estuary, extending westward from Ponta Maona (cf. Figure 2), has an irregular bathymetry (maximum depth of $18 \mathrm{~m}$ and average $3-4 \mathrm{~m}$ ), characterized by sand platforms, a main channel, and tidal plains. In the right bank of the estuary (included in the Katembe area) there is a large tidal zone, where mangrove and other wet areas develop. In the same bank, progressing to Ponta Maona, the coastline presents an arch form with unsubmerged continuous and narrow sandy beach, bordered by a front dune chain. The Maputo Bay is a shallow inlet, where depths larger than $5 \mathrm{~m}$ comprise only $35 \%$ of its area, mainly in the West part. The bank following Ponta Maona is defined by cliffs.

Due to the smooth terrain, the main erosion and slope instability risks are verified in the coastal area at the banks of the estuary and Maputo Bay. The current most critical situation is verified in Ponta Chaluquene with very high instability and extensive erosion associated to river and tidal currents of the estuary. The situations of cliff instability are connected mainly to the effect of rainwater and surface runoff and translate a susceptibility to occurrence of slope mass movements. A high susceptibility to instability is found in the coastal arch, extending to Ponta Maona, expressed by blocks' fall or toppling (Figure 4).

In the East estuary and Maputo Bay, accretion dominates over erosion in the long-term. Sediments are provided by river flows, but also by the erosion of cliffs and old reefs, in this case especially due to surface runoff in the occurrence of cyclonic events and tropical storms.

The pressure over the coastal area is expected to increase with the urban development of Katembe, possibly affecting its function in inland protection from sea advance. The urbanization of coastal areas will increase the risks of cliff instability concerning the exposure of people and property. The possible sea level increase, related to global climate change, together with the gradual regularization of rivers and possible change in-land use in the watersheds may increase the accretion of the estuary, increasing erosion in beaches bordering the bay.

\subsection{Climate and water}

The climate in the Maputo region is tropical, savanna-type and semi-arid. Precipitation is larger in the summer period, 

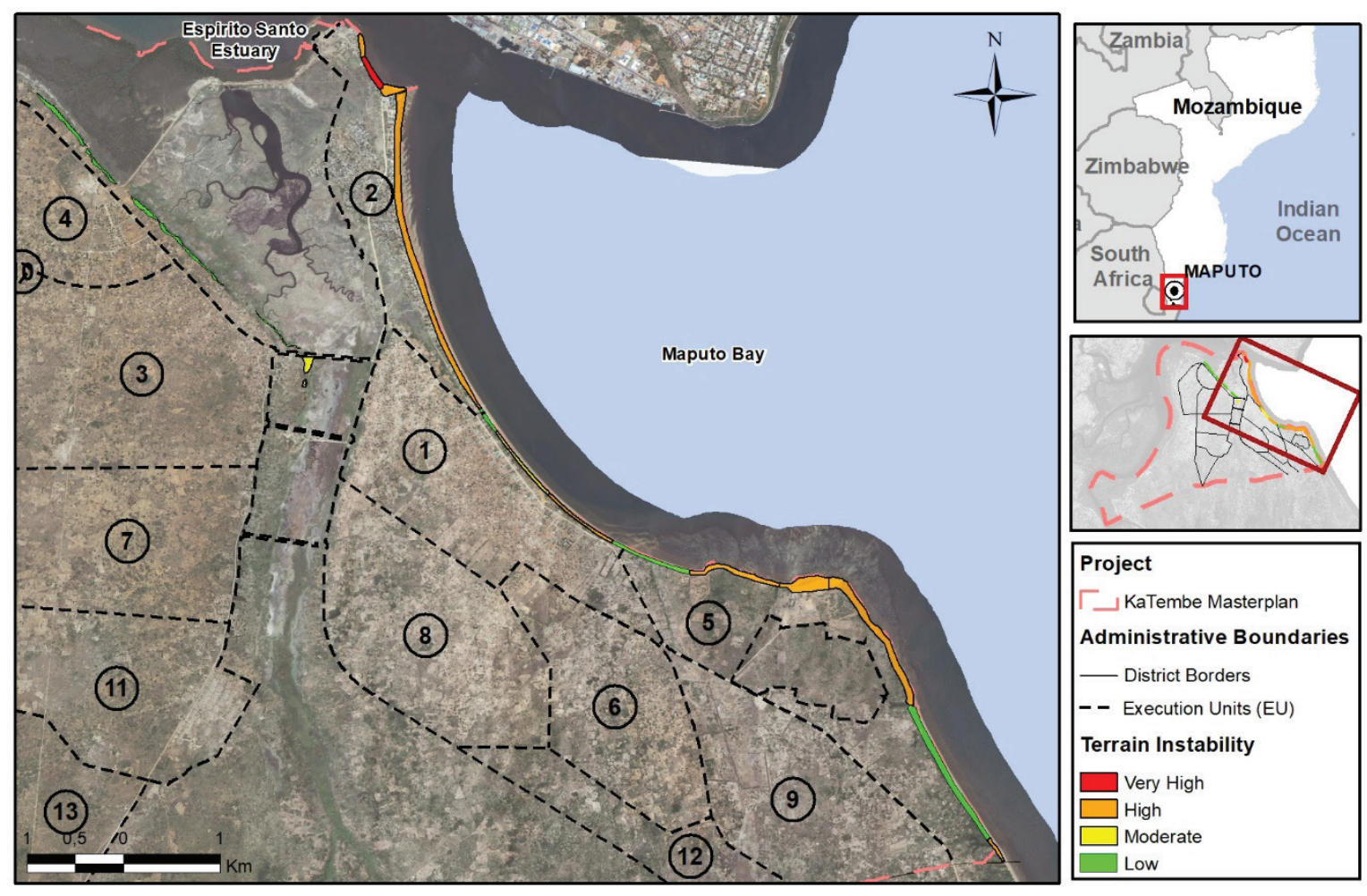

Figure 4. Instability in Katembe's coastal area

Source: Adapted from Betar et BETA (2012)

between November and March (73\% of total annual precipitation of nearly $600 \mathrm{~mm}$ ). The average air temperature varies between $27^{\circ} \mathrm{C}$ in the summer and $21^{\circ} \mathrm{C}$ in the winter. The coastal area can be affected by intense precipitation and winds during several days in the events of tropical cyclones, typically in summer time.

River Tembe (cf. Figure 5) marks the West limit of Katembe territory. Its flow is markedly seasonal (Lencart e Silva et al., 2010), amounting to $140 \mathrm{M} \mathrm{m}^{3}$ annual average, produced in a hydrographic basin of $2.864 \mathrm{~km}^{2}$. Besides River Tembe, which extends for $125 \mathrm{~km}$ from the spring in Swaziland, the territory is characterized by the presence of the water course of Vale de Xandane/Bangoloene swamp, extending from South to North for $22 \mathrm{~km}$. The Vale de Xandane water course presents a $109 \mathrm{~km}^{2}$ hydrographic basin, with annual average flow of 9 $\mathrm{M} \mathrm{m}^{3}$, peaked (57\%) in the October-January period.

The main tributary to the Espírito Santo Estuary is River Umbeluzi (cf. Figure 2), with a hydrographic basin of 5.600 $\mathrm{km}^{2}$, and an extent of $314 \mathrm{~km}$ from its spring in Swaziland. The place of several large dams (including the Pequenos Libombos, the main water source of Maputo City), River Umbeluzi has a regular flow along the year, with average annual flow of $500 \mathrm{M} \mathrm{m}^{3}$ (Hoguane, 1999).

Floods have historical presence in the Espírito Santo Estuary banks, andthe event of Feb 2000 in the last decade, which was caused by intense precipitation and exceptional river flows, should be highlighted. A specialized study on flood risk in the Katembe territory found that this area is more vulnerable to meteorological elevations of sea level (associated with atmospheric depressions) than to river caused floods. In fact, Katembe is protected from the most frequent floods by an estuary-side road and cliffs in the North, because the water course of Vale de Xandane connects to the estuary through a hydraulic passage. The collapse of this dike or the change in the hydraulic passage could cause a dramatic increase of flood vulnerability of the Katembe territory.

In the flood risk assessment carried out, most of Katembe territory was classified with low risk. However, high risk areas are assessed in the areas connecting with the Vale de Xandane water course and in the Northeast boundary, confining with the estuary: including the marginal road sided by the estuary and in some areas of the Guachene neighborhood.

In River Tembe the most important pollution sources are the domestic effluents, biomass combustion products and nutrients from farmlands along the river. These sources also affect directly the Espírito Santo Estuary and Maputo Bay, and additional pollution is generated by industrial effluents in Maputo and Matola and by the marine transportation operations in Katembe pier and Maputo Port. In the tributary rivers the domestic and industrial effluents are predominant water pollution sources. 


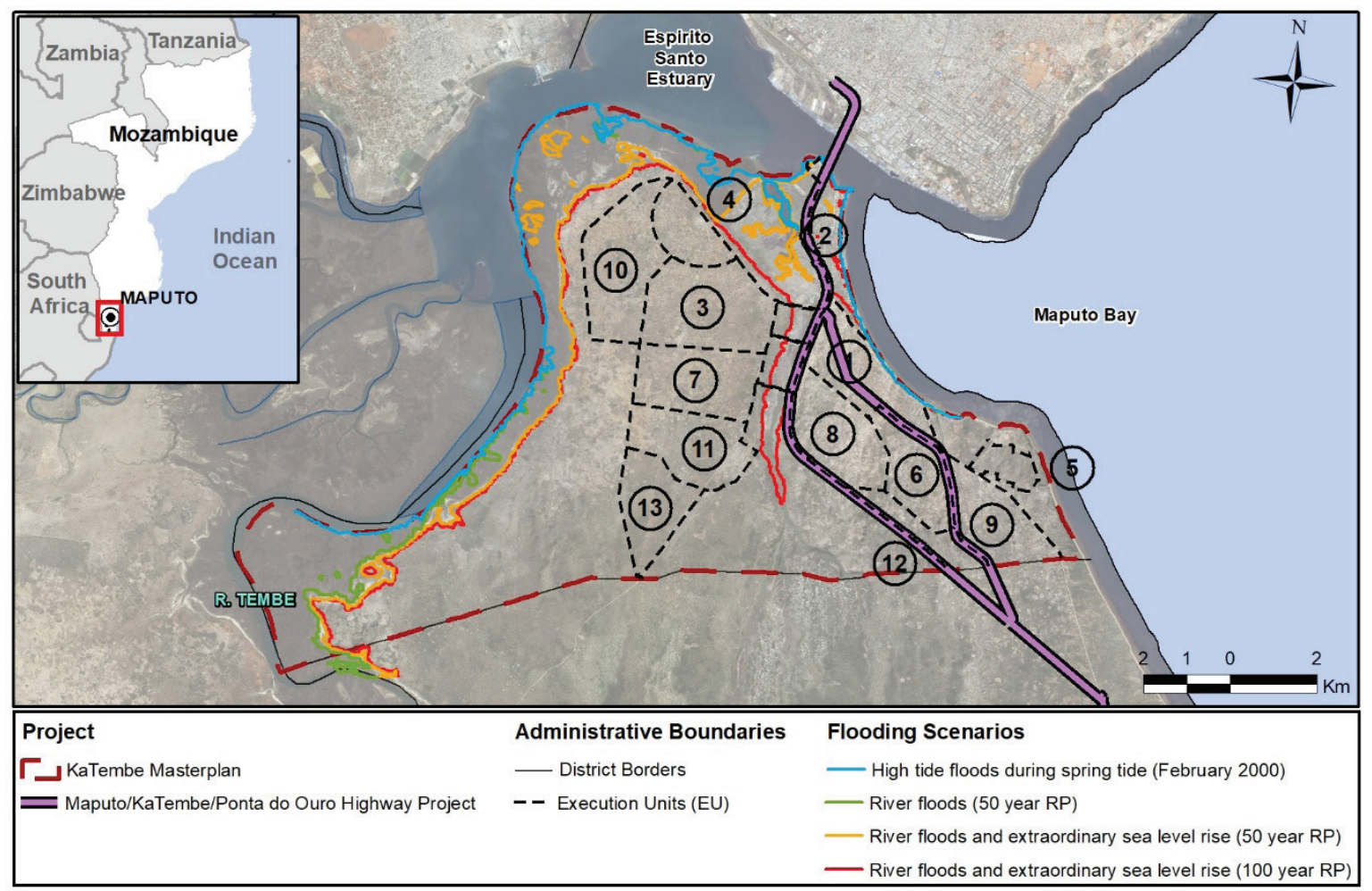

Figure 5. Flooded area limits in Katembe territory

Source: Adapted from Betar et BETA (2012)

Water quality is monitored only in the hydrographic basins of rivers Umbeluzi, Matola and Infulene, although not regularly. Main problems concern turbidity, dissolved oxygen, and nutrients (ARA-Sul, 2010). In the estuary and Maputo Bay the water quality is degraded by human activities (Sete et al., 2002; Collin et al., 2008).

Groundwater is widely used in Katembe for public supply through bored or dug wells. Only the actual neighborhoods of Chali, Inguide and Guachene have tap water supplying systems, which are based on groundwater $\left(10 \mathrm{~m}^{3} / \mathrm{h}\right)$. Access to water is a main source of daily hassle for Katembe population. Besides using seven public supply wells, connected with the deep aquifer, the population explores 66 other groundwater sources, in the upper aquifer, for meeting its daily needs. The water sources are concentrated in the near East and North limits of the territory, forcing the population to travel several kilometers to reach water.

The upper aquifer shows relatively high mineralization which can be caused by hydraulic connectivity with sea or estuarine water, geological origin, or eventual inadequate exploration of wells. This greatly limits its use for human or cattle consumption or for irrigation.

The perspective of the maintenance of sanitation problems in Katembe should cause the persistence or even aggravation of surface water quality problems in the territory.
The unplanned expansion of urban areas, especially in the neighborhood of Guachene and northern coastal area of Chali neighborhood, should increase the exposure of the population and properties to floods.

It is expected that consumption of groundwater will increase in the future, with the creation of new wells, given the probable expansion of the urban area of Maputo and the objective of Mozambican Government to provide access of safe water to rural areas and towns all over the country (República de Moçambique, 2010; República de Moçambique, 2015b). New pressures may also arise affecting groundwater quality.

Climate change, including higher air temperatures and a summer precipitation increase, and rise of sea surface levels, may have effects in the quality and quantity of groundwater. The expected sea level increase between 0,3 and 0,5m, in the period 1990-2100 (Santos et al., 2002) may accentuate the mineralization of coastal aquifers.

\subsection{Biodiversity}

Despite the human influence in the Katembe territory, the presence of the estuary, the bay and the rivers award the area a considerable ecological value. 
Brazilian Journal of Operations \& Production Management

Volume 15, Número 2, 2018, pp. 270-284

DOI: 10.14488/BJOPM.2018.v15.n2.a9
In the Southwest, Katembe intersects only marginally the Transfrontier Conservation Area of Libombos, established in 2000 between the Governments of Mozambique, Swaziland and South Africa.

The habitat with greater expression in Katembe is the semi-natural "agricultural fields and land with farming use" (54\% of the area). Secondly, the group of "dense bushes and woods" ( $26 \%$ of the area, mostly in the South. Finally, "sand and silt tidal areas", representing about $10 \%$ of the territory, mainly in the West. The Katembe area is divided in two (West and East) by the Bangoloene swamp, which includes a permanent water table and riverside vegetation patched with marshes.

Areas of very high ecological value located in the borders of the Katembe territory: mangrove areas in the banks of River Tembe (West) and bushes in the South, together with the Bangoloene swamp's patch of marsh and riverside vegetation areas. The sand and silt tidal areas near River Tembe's mouth and the Espírito Santo Estuary and the sand and bush dunes in the banks of Maputo Bay are ranked with high ecological value.

With the foreseen urban development of Katembe, it is predicted that pressures on ecosystems will increase through the exploration of fauna resources, change in agriculture land-use, deforestation, water pollution, increased erosion in beaches and dunes, potentially affecting the river and coastal areas with highest ecological value.

\subsection{Socioeconomics and community development}

Land-use in the Katembe territory is predominantly for farming and livestock (31\%), wetland and flood plains at the bank of River Tembe and in Bangoloene swamp (19\%), naturally wooded vegetation areas (15\%) and farming lands patched with unplanned urban areas (12\%). Actual urban areas, although with incomplete infrastructures and organized around unpaved roads, represent only $1 \%$ of the territory.

In the context of the City of Maputo, Katembe is the second municipal district with lower population (only 19.371 inhabitants in 2007 census, INE) and the population density is substantially smaller than the municipal districts in the north bank of Espírito Santo Estuary: 192 inhab./km² facing 3.163 inhab. $/ \mathrm{km}^{2}$ in the whole City of Maputo.

The population of Katembe is concentrated in the Guachene and Chali neighborhoods (respectively 1.226 and 496 inhab./ $\mathrm{km}^{2}$ ), with close access to Maputo centre by ferryboat.

Inguide and Chamissava are the neighborhoods with the largest population growth in recent decades $(3,86 \%$ and
6,84\% between 1997-2007), probably due to overpopulation in the northern neighborhoods and the attractiveness of the existent road to Matutuine District Capital Bela Vista.

The actual urban spaces concentrate in Chali and extend to Guachene and Incassane along the coastline. Other unplanned urban spaces result from the densification of old informal settlements, around very narrow dirt roads, with most houses made of concrete blocks or bricks. Disperse unplanned urban spaces have typically houses made of organic materials as wood (Figure 6).

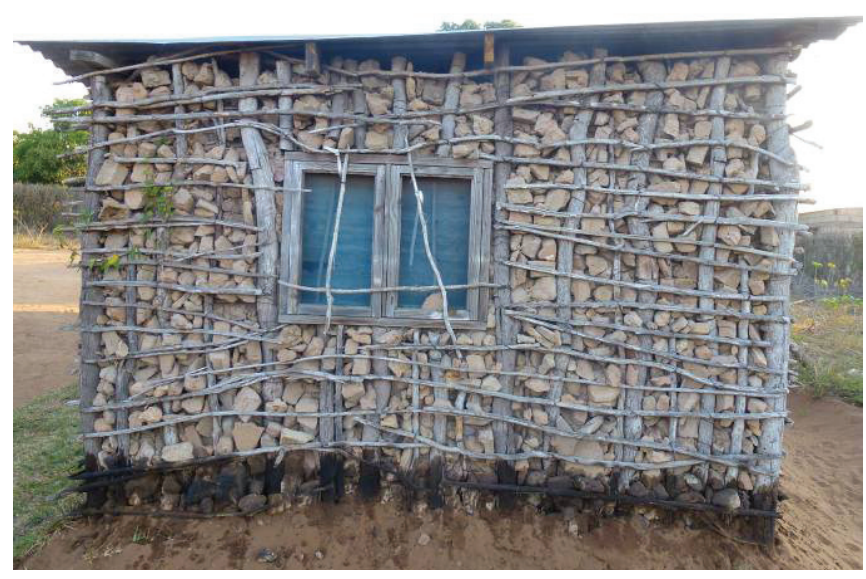

Figure 6. House typical of disperse unplanned spaces Source: Betar et BETA (2012)

Katembe's local urban infrastructures, including roads, water supply and sewage and waste collection, are inadequate for the current population's needs. There is no sewage or storm water drainage system.

Most of the active population of Katembe have informal jobs, predominantly in land cultivation and livestock farming activities. The formal sector employs only about $5 \%$ of the population in working age (from 15 to 65 years of age). The population growth experienced in Katembe is not assisted by an extension of employment in the formal sector, despite an important part of the population having basic education: only about half of Katembe's population is illiterate (54\%), relative to the country situation (72\%).

Despite farming absorbing an important part of the population of Katembe, agricultural production is pre-empted by adverse conditions, such as low soil fertility, lack of adequate infrastructure and accessibilities.

The territory includes one known archaeological site in Ponta Maona (Senna-Martinez, 1975), discovered in the sequence of cliff instability. It is possible that other archaeological sites may be yet to be discovered in the 
Katembe's coastal area and estuary and River Tembe's banks.

Katembe is the place of expression of the intangible heritage of its population. This consists mainly in the maintenance of traditional burial grounds with some connection to natural environment (Betar et BETA, 2012).

It is foreseen, especially with the implementation of the Highway Maputo/Katembe/Ponta do Ouro, that Katembe territory will expand the urban areas. The unplanned pressure on natural or semi-natural areas of riverside and estuarine wetlands and the coastal zone may easily accomplish a degradation of Katembe's landscape. The influx of population from Maputo City is continuous and by an estimate, even without the city's construction, the population of Katembe should reach a value between 54 to 89 thousand inhabitants in 2040, a value threefold or even higher than the 2007 level.

Population growth should have an effect on housing numbers, and in the economic activities of the territory. It is foreseen the development of small commerce, private public transportation by road, especially along the main roads. Farming production may show some decline.

It is possible that the material heritage may be conserved in conditions similarly to actuality. However, an important threat to known and yet to be discovered heritage is posed by continued erosion in the coastal area. The maintenance of the traditional burial grounds is also threatened by the weakening of community bonds and unsustainable exploitation of natural resources (Betar et BETA, 2012).

\section{ENVIRONMENTAL AND SOCIAL IMPACTS AND MEASURES}

The environmental and social studies supporting the urban planning concluded that the building of a new city in Katembe could originate negative environmental and social impacts, even after a careful urban planning avoided most high risk areas. Environmental residual impacts, classified with moderate to high significance, include:

- Local climate may be adversely altered in case closed city blocks are implemented;

- $21 \%$ of the territory may verify soil change and loss through sealing;

- Increased pressure on the coastal zone, may affect cliff and sand dunes stability;
- Increase of groundwater consumption may compromise aquifer sustainability;

- Flood risk is moderate to high in the northeast of the territory, where the urban plans predicts a low-density occupation;

- $15 \%$ of the planned urban areas overlap bush areas with very high ecological relevance.

Hence, most of the impacts correspond to the worsening of evolution trends already felt in the territory, as presented in section 3 .

The environmental findings identified in the background studies of river flow and flood risk assessment, and also of climate change and coastal and estuarine hydrodynamics, were integrated in the urban plans as no construction areas constituting coastline and watercourses protection buffers; all of these no building proposals were respected in Katembe City Master Plan: no urban development was proposed for high risk areas, and only low density urban areas were allowed in moderate risk areas.

Furthermore, the ESIA recommended additional measures to reduce residual negative impacts. From the set of proposed measures, the following are highlighted:

- Implementation of sand dunes stabilization and rehabilitation projects in Katembe's coastal arch;

- Access to cliffs with high susceptibility to instability should be prevented;

- Specific geotechnical studies to be required prior to any expansion or transformation of buildings located in the proximity to cliff edges;

- Implementation of a program for the monitorization and control of cliff evolution;

- Any new intervention in flood prone areas requires detailed studies on flood risk;

- The Municipal Council should implement flood warning systems;

- A groundwater availability assessment study was required to define criteria for sustainable use;

- The Municipal Council should implement separative systems for rainwater collection and reuse; 
- The new city should implement a network for water quality monitoring;

- Development and implementation of an ecological and environmental requalification plan for Bangoloene swamp;

- Building specifications in urban areas should ensure adequate ventilation conditions;

Regarding socioeconomic impacts, the most important negative impacts (moderate to high significance), concern the intensification of trends already present in Katembe's rural areas:

- Continuing spontaneous land occupation with informal settlements;

- Construction of new urban areas require previous relocation of rural families, impacting on farmers' activities, local workshops, trade and services, with the potential to significantly affect families' income;

- Migration of non-local people can cause cultural shocks with local populations;

- Eventual creation of a socially divided urban space, especially if Katembe is to become the site for resettling the population of the newly planned neighborhoods of Maputo City;

- Social exclusion of a significative part of the inhabitants, with lower incomes, in case public transportation system and pedestrian and bicycles networks are not implemented.

- Traditional burial sites may be adversely affected in case no specific protection is provided;

The sensible issue of cultural heritage is considered directly in the urban plans through safety and protection zones included as constraints to urbanization.

To deal with the residual negative socioeconomic impacts, the ESIAs proposed a set of minimization measures, including the following recommendations:

- Assure the distribution of land to farmers' cooperatives and associations;

- Avoid private condominium housing solutions;

- The Municipal Council should address future mobility needs and plan accordingly;
- Perform regular audits in the intervention areas of the approved detail plans to control unplanned developments

- Assess the evolution of Katembe's resident population, through regular surveys.

\section{DISCUSSION}

Given Katembe's physical, ecological and social backgrounds, the planning methodology for a sustainable and sound urban development, included:

- The sequential land management approach, progressing from a regional to a local level;

- The special focus on avoiding environmental risks at an initial stage of city planning (master plan level);

- The special focus on social, cultural and resettlement policies at the local (city's sectorial areas) urban planning level.

In fact, the planning sequence enabled one interactive assessment of the territory firstly to address strategic issues (location of large housing projects, major infrastructure and accessibilities) at the regional scale, zoning land use in Katembe and Matutuíne districts, and selecting the areas with the most favorable environmental and socioeconomic conditions.

Secondly flooding risks, coastal dynamics, and ecological vulnerabilities were investigated in specific detailed studies, to define no construction areas in the Master Plan of the city, to adequately address physical and ecological concerns.

In the following third phase, more detailed approaches of community development, housing, cultural heritage and resettlement needs, were carried out to achieve liveability objectives for the new urban developments.

The whole processed benefited from the close interaction of the urban and engineering planners on one side, and the environmental and social experts on the other. Moreover, the engagement of local communities, NGOs, public institutions and local authorities was essential and made possible through a continued participatory process.

Currently, the urban plans for Katembe have been discussed, approved, and published. Environmental studies have also been approved and are public domain. Resettlement plans have, until recently, yet to be concluded. 
The major concerns for the next steps correspond to a proper implementation of the Master Plan, and the Sector Area Plans; governance, housing and resettlement, resource use, and accounting of environmental risks, all remain crucial for the successful implementation of the new city.

Due to the completion (expected in 2018) of the new bridge linking to Maputo's city centre, Katembe's population is expected to rapidly increase, changing from the current low density, mostly rural, settlements where communitarian ancestral lifestyles prevail. Hence, the respect for local culture and land-use rights should be present in the application of different instruments of urban governance:

- Future urban management must be able to enhance the communitarian sense which characterizes todays settlements, and must be very strict in the control of spontaneous land occupation;

- The funding model for the city development should address different situations and goals. On one hand funding must assure favorable conditions for low income settlements, sharing the costs of low income property development between donors, and public and private entities. On the other hand, attracting potential promoters from medium to high income settlements is also critical (Betar et BETA, 2012);

- Urban development should be flexible enough to progressively integrate the information resulting from local partnerships and public participation (local communities and agents, and local authorities). Inclusive development should be regarded as an opportunity and not as a threat.

- To learn and profit from local urban experiences (e.g. inclusive housing and infrastructure projects by NGOs) is mandatory.

The redevelopment rehabilitation and consolidation of the actual settlements is very important for the development of Katembe territory, because these are the areas that will ensure the specific (and unique) identity of the new city and allow the preservation of cultural and patrimonial heritage. For the adequate development of the urban space the old and the new settlements should be connected, creating a city in the diversity.

Most of the area for residential use in Katembe's approved Master Plan is intended for social housing (54\%). Due to this prominence, and taking into account social vulnerabilities, social housing should have a specific pro- gram, articulated with the Master Plan development, defining specific directives and objectives for each area. This definition should be based on the social objectives intended to be fulfilled in each community. In this process care should be taken to avoid social segregation. One integrated and spatially non-segregated social housing program should also foster the needed social control of urban spaces, to achieve increased security.

Focus on resource use is required due to the extended time horizon of the new city, and the need to address basic living means of low income population. Thus, it is crucial to manage resource demand (e.g. water, energy, farmland) through infrastructure optimization, and the design of the open space network (essential to water sustainability) and the mobility, local facilities, and buildings (essential to energy sustainability). It is also very important to monitor the environmental performance of the city, through the regular measurement of environmental and social indicators.

Environmental vulnerabilities and risks already existent in today's Katembe, are expected to increase significantly in a near future. Hence, detailed geotechnical assessment should be performed prior to any construction works within $50 \mathrm{~m}$ inland from cliffs. Depending on specific findings, additional regulation measures can be implemented to ensure protection of coastal geomorphology. The intervention in flood prone areas also require preventive measures directed to construction projects, as well as contingency plans and adequate drainage infrastructure.

Water quality is essential to support existent and predicted uses, such as human supply and bathing. The development of Katembe City can exacerbate surface and ground water problems, hence implemented sanitation solutions will require follow-up and regular monitoring of water quality, to allow eventual corrections.

Most habitats of high to very high ecological value are protected (as these were integrated in a Green and Ecological Structure of the city). However, it is expected that these habitats should be subjected to additional anthropic pressure. Hence, additional measures might be required to ensure the preservation of notable and cultural landscape aspects.

According to the level of accounting of all these aspects in the city's implementation process, different final scenarios for Katembe can be outlined:

- A fragmented city arising from mostly unplanned urbanization, influenced by the occasional land availability and by larger urban pressure. This 
Brazilian Journal of Operations \& Production Management

Volume 15, Número 2, 2018, pp. 270-284

DOI: 10.14488/BJOPM.2018.v15.n2.a9 scenario, linked with the absence of a clear governance structure and of the lack of proper implementation of the environmental and social recommendations, facilitates the deterioration of urban and environmental quality: the outcome is a fragmented city, with social and cultural vulnerabilities and poor environmental records.

- A structured city: implemented according to the approved urban plans (master and sectorial) and recommendations (SEA and ESIAs), respecting the intended execution schedule, and achieving a high level of governance - the outcome is a sustainable and qualified urban environment.

\section{SUMMARY AND CONCLUSIONS}

The paper presents and discusses the methodology used to approach the urban planning of a new city in Katembe territory, South Mozambique, to accommodate the expected expansion of the Mozambican Capital City Maputo's population.

Based on the perception that efficient urban planning and local development management is achieved through the accounting of sustainability (economic, environmental, and social), and also of liveability, which is a concept that comprises the three-dimensional aspects of public space and its spontaneous appropriation, a methodology for the urban planning of Katembe was designed.

This methodology, intending to ensure the planning process to be flexible, adaptive and with the stakeholder's participation, has as main features:

- Sequential approach in three phases from regional planning (first phase), following to master plan (second phase) and to local/sectorial planning (third phase);

- Integration, in each phase, of the urban planning with environmental and social approaches, comprising SEA (on the first phase of regional planning) and ESIA (on the second and third phases, Master and sectorial planning), together with specific studies concerning environmental and social risks;

- Several participatory instances for the public and institutions available in the urban planning and environmental and social assessments of individual processes, ensuring the involvement of stakeholders;
- Approval of urban plans and environmental and social studies by the competent municipality and environmental assessment authorities, engaging the governance institutions and fostering the required adaptation.

Given the vulnerabilities and environmental and social backgrounds of Katembe's territory, the application of this methodology proved to be effective. Namely, the first phase allowed territorial zoning and the identification of the area with the most favorable environmental and socioeconomic conditions for the city's development. In the second phase, the city's land use was further defined and restricted, having into account the relevant environmental and social risks. Finally, in the last sectorial phase specific issues concerning resettlements and neighborhoods building were addressed.

Currently the first two phases are concluded, and the urban plans and environmental and social studies were approved and published. The completion of the last phase (sectorial planning) awaits the conclusion of the sectorial resettlement plans.

In this context, despite the availability of approved urban plans, the undesirable scenario of a fragmented city in Katembe could still become a reality, and the aimed improvement of its population living conditions could be relatively reduced. Spontaneous occupation of the territory could undermine the adequate planning and management of today's and future settlements, making the concretization of the new city's ambitious objectives very difficult.

Hence, major concerns for the next steps refer to urban planning implementation issues, related to strengthening governance, adequate housing, settlement and resettlement policies, controlled resource use and accounting of the environmental risks.

Provided adequate integration of these aspects, the accomplishment of a well-structured major city in Katembe's is possible in a 20-30 years' time. Progressive implementation of the plans' objectives and expected yields in population's living quality and land development should contribute to the significant sustainable development of this region.

\section{REFERENCES}

ARA-Sul (2010), Estado da Qualidade de Água na Região Sul de Moçambique - Período de Abril a Junho de 2010, Administração Regional de Águas do Sul, Maputo, Moçambique. 
Beatley, T.; Manning, K. (1997), The ecology of place: Planning for environment, economy, and community, Island Press, Washington, D.C., USA.

Betar; BETA (2012), Estudo de Impacto Ambiental do Plano Geral de Urbanização do Distrito Municipal da KaTembe, Conselho Municipal de Maputo and Empresa de Desenvolvimento de Maputo Sul, E.P., Maputo, Moçambique.

Betar; BETA (2013), Estudo de Impacto Ambiental do Plano Parcial de Urbanização da Unidade de Execução 3 do Plano Geral de Urbanização do Distrito Municipal KaTembe, Conselho Municipal de Maputo and Empresa de Desenvolvimento de Maputo Sul, E.P., Maputo, Moçambique.

Betar; BETA (2013), Estudo de Impacto Ambiental do Plano Parcial de Urbanização da Unidade de Execução 10 do Plano Geral de Urbanização do Distrito Municipal KaTembe, Conselho Municipal de Maputo and Empresa de Desenvolvimento de Maputo Sul, E.P., Maputo, Moçambique.

Betar; BETA ; Nemus (2012), Avaliação Ambiental Estratégica do Plano de Desenvolvimento Regional KaTembe - Ponta do Ouro, Empresa de Desenvolvimento de Maputo Sul, E.P., Maputo, Moçambique.

Betar; BETA ; Nemus (2012), Plano de Desenvolvimento Regional KaTembe - Ponta do Ouro, Empresa de Desenvolvimento de Maputo Sul, E.P., Maputo, Moçambique.

Betar; BETA; Nemus (2012), Estudo de Hidrodinâmica na Baía de Maputo/Estuário do Espírito Santo, Empresa de Desenvolvimento de Maputo Sul, E.P., Maputo, Moçambique.

Betar; Promontório Architects (2012), Plano Geral de Urbanização do Distrito Municipal da KaTembe, Empresa de Desenvolvimento de Maputo Sul, E.P., Maputo, Moçambique.

Betar; Promontório Architects (2013), Plano Geral de Urbanização da Unidade de Execução 10 do Distrito Municipal da KaTembe, Empresa de Desenvolvimento de Maputo Sul, E.P., Maputo, Moçambique.

Betar; Promontório Architects (2013), Plano Parcial de Urbanização da Unidade de Execução 3 do Distrito Municipal da KaTembe, Empresa de Desenvolvimento de Maputo Sul, E.P., Maputo, Moçambique.

Collin, B. et al. (2008), "Fecal Contaminants in Edible Bivalves from Maputo Bay, Mozambique: Seasonal Distribution, Pathogenesis and Antibiotic Resistance", The Open Nutrition Journal, No. 2, pp. 86-93.

Direcção Nacional de Gestão Ambiental (2006), Avaliação das Experiências de Moçambique na Gestão de Desastres Climáticos (1999 a 2005), Ministério para a Coordenação da Acção Ambiental, Maputo, Moçambique.
Godschalk, D. (2004), "Land Use Planning Challenges: Coping with Conflicts in Visions of Sustainable Development and Livable Communities", Journal of the American Planning Association, Vol. No. 1, pp. 5-13.

Grieve, J.; Weinspach, U. (2010), Capturing Impacts of Leader and Of Measures to Improve Quality of Life in Rural Areas, European Communities, Brüssel, Belgium.

Hegmann, G. et al. (1999), Cumulative Effects Assessment Practitioners Guide, AXYS Environmental Consulting Ltd. and the CEA Working Group for the Canadian Environmental Assessment Agency, Hull, Quebec.

Hoguane, A. (1999), Sea Level Measurement and Analysis in the Western Indian Ocean, National Report Mozambique, Maputo, Moçambique.

IFC - International Finance Corporation (2013), Good Practice Handbook. Cumulative Impact Assessment and Management: Guidance for the Private Sector in Emerging Markets, International Finance Corporation, Washington D.C., USA.

INE (2007), Censo 2007, Instituto Nacional de Estatística de Moçambique.

Lencart e Silva, J. et al. (2010), "Buoyancy-stirring interactions in a subtropical embayment: a synthesis of measurements and model simulations in Maputo Bay, Mozambique", African Journal of Marine Science, Vol. 32 No. 1, pp. 95-107.

República de Moçambique (1997), “Lei n.o 19/97 de 1 de outubro - Lei de Terras", Boletim da República, I Série, No. 40, pp. 15-9.

República de Moçambique (2010), "Programa Quinquenal do Governo para 2010-2014", Governo de Moçambique, Maputo, Moçambique, available from: www.portaldogoverno.gov.mz/por/content/download/1959/15690/version/1/file/Plano+Quinquenal+do+Governo+2010-14.pdf (access on 2018 May 21).

República de Moçambique (2015), “Decreto n.ㅇ 54/2015 de 31 de dezembro - Regulamento Sobre o Processo de Avaliação do Impacto Ambiental", Boletim da República, I Série, No. 104, pp. 484-503.

República de Moçambique (2015), “Programa Quinquenal do Governo 2015-2019, Governo de Moçambique, Maputo, Moçambique", available from: www.portaldogoverno.gov.mz/por/content/download/1960/15695/version/1/file/Plano+Quinquenal+do+Governo+2015-2019. pdf (access on 2018 May 21).

República Portuguesa (2007), “Decreto-Lei n.으 232/2007 de 15 de junho - Regime a que fica sujeita a avaliação dos efeitos de determinados planos e programas no ambiente", Diário da República, 1.a Série, No. 114, pp. 3866-71. 
D Brazilian Journal of Operations \& Production Management Volume 15, Número 2, 2018, pp. 270-284

DOI: 10.14488/BJOPM.2018.v15.n2.a9
República Portuguesa (2011), “Decreto-Lei n.o 58/2011 de 4 de maio - Alteração ao Decreto-Lei n.o 232/2007, de 15 de junho", Diário da República, 1.a Série, No. 86, p. 2533.

Santos, F. et al. (2002), Climate changes in Portugal. Scenarios impacts and adaptation measures, SIAM Project, Gradiva/Fundação Calouste Gulbenkian/FCT, Lisboa, Portugal.

Senna-Martinez, J. (1975), "A Idade do Ferro em Moçambique: algumas notas para a compreensão da sua origem e difusão", paper presented at: Seminário de História de Moçambique Pré-Colonial, Universidade Eduardo Mondlane, Maputo, 1975.
Sete, C. et al. (2002), Seasonal Variation of Tides, Currents, Salinity and Temperature along the Coast of Mozambique, UNESCo (ICO) / Centro Nacional de Dados Oceanográficos.

Steiner, F. (2002), Human ecology: Following nature's leaf, Island Press, Washington, D.C., USA.

Teixeira, L. (2013), Megaprojetos no litoral norte paulista: o papel dos grandes empreendimentos de infraestrutura na transformação regional, Tese de Doutorado em Ambiente e Sociedade, Instituto de Filosofia e Ciências Humanas, Universidade Estadual de Campinas, Campinas, SP, Brasil.

Received: 28 Dec 2017

Approved: 08 May 2018

DOI: 10.14488/BJOPM.2018.v15.n2.a9

How to cite: Coutinho, P. B. (2018), "Sustainable Planning of a New City in Mozambique", Brazilian Journal of Operations \& Production Management, Vol. 15, No. 2, pp. 270-284, available from: https://bjopm.emnuvens.com. $\mathrm{br} / \mathrm{bjopm} / \mathrm{article} / \mathrm{view} / 424$ (access year month day). 